\title{
THE ROLE OF THE TECHNOLOGY AREA IN THE ANALOG SWITCH-OFF PROCESS AND THE START OF THE 4G / LTE IN THE 700 MHZ BAND
}

\section{Chair: Rafael Leal - TV Globo}

This session will discuss technical aspects related to the analog TV switch-off, issues related to the various channel reassignments for clearing the $700 \mathrm{MHz}$ band as well as discussions about the actions preceeding and following the activation of $4 G$ / LTE in this band across the country. We will have the participation of the professionals who are heavily involved in all these processes that will be able to share with the public their recent experiences on these three fronts: switch-off, repacking and activation of $4 \mathrm{G}$ / LTE in the $700 \mathrm{MHz}$ band.

- ANALOG SWITCH-OFF IN BRAZIL- HOW TO CONDUCT Speaker: Carlos Cauvilla / Diretor de Tecnologia de TV / Rede Anhanguera Will be addressed in this presentation some points on how to prepare for the switch-off of analog signals including digital coverage assessment, training of technical staff and dissemination of actions. What are the roles of engineering in the pre- and post switch-off periods. How should the technology support other areas in the process of awareness of the erasure of analog signals?

- WHAT SHOULD I KNOW ABOUT THE BEGINNING OF THE 4G / LTE OPERATION IN THE 700MHZ BAND? Speaker: Luiz Fausto - Regulatory Strategy Specialist for Globo TV Network This presentation will cover the main points related to the beginning of the 4G / LTE operation in the $700 \mathrm{MHz}$ band in Brazil, in relation to the coexistence with the TV transmissions in the adjacent band. The preventive and corrective measures adopted to avoid possible problems of harmful interference will be described, highlighting the most important aspects to be followed by the broadcasters. 


\section{- THE ELECTRONIC WASTE, SUSTAINABILITY, OBLIGATION,} RESPONSIBILITY

\section{Speaker: Mara Raquel Ballam - Executive Manager of ABREE}

Mara Ballam, from ABREE - the Brazilian Association for Electro electronics and Home appliances Recycling - will address the challenges of the electronics sector for the implementation of reverse logistics and its environmental, social and economic impact.

\section{- REPACKING OF TV CHANNELS}

\section{Speaker: Fernando Gomes de Oliveira - Management and project planning - Be Digital}

The repacking may require changing the antenna, transmitter, filters, etc., and each project is different. As part of the government bid, buyers of this frequency band have the responsibility of redistributing 1034 TV channels, following the analog TV shutdown schedule, which will be completed by the end of 2018, when the spectrum will be released for the activation of the the next generation of mobile broadband.In this presentation we will cover the main stages of this process.

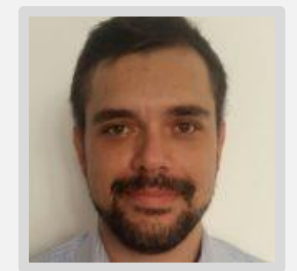

\section{Rafael Leal - TV Globo}

Rafael Leal holds a degree in Telecoms Engineering from INATEL, a graduate degree in Business Administration from the FGV-SP and an MBA in Project Management, also from FGV-SP. He has more than 10 years' experience in television engineering, and has been working for 8 years at TV Globo. He worked for 6 years in support and technical interface area with affiliated station, having dedicated himself to regulatory matters and having worked closely with the analog TV disconnection and digital signal expansion processes throughout Brazil. He is deputy coordinator for the Market Module at the FBTVD (the Brazilian Digital TV Forum), coordinator of the SET Switch-Off Working Group and a member of the GT-Rm (Reallocation Technical Group) of the GIRED.

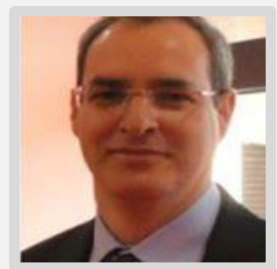

\section{Carlos Cauvilla / Diretor de Tecnologia de TV / Rede Anhanguera}

Engineer with an MBA in Business Management and Technology Management. Currently holds the position of Director of TV Technology at Anhanguera Network, where he is responsible for the operation, projects and implementation of technologies aimed at the Media TV business. Actively participating in its third analog disconnection in Brazil, in the Goiânia cluster

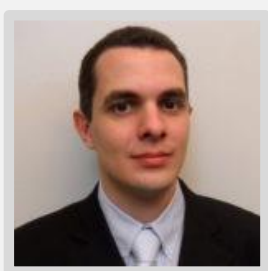

\section{Luiz Fausto - Regulatory Strategy Specialist for Globo TV Network}

Professional Master's Degree in Applied Computing (UECE - 2015), Executive MBA on IT (UFRJ - 2011), extension course in Networks and Video over IP (UFRJ - 2009), Bachelor's Degree in Electrical Engineering with emphasis in Electronics (UFRJ/USU - 2005). Currently working as Regulatory Strategy Specialist for Globo TV Network, Deputy Director of the Technology Board Committee of the Brazilian Television Engineering Society (SET), member of the Delegation of Brazil in ITU-R (SG 6) and CITEL (PCC.II), member of the TV Reception Technical Group (GT-Rx) of the Brazilian TV Switch-Over Group (GIRED), member of the Technical Module of SBTVD Forum and member of the Harmonization Working Group of ISDB-T International Forum 


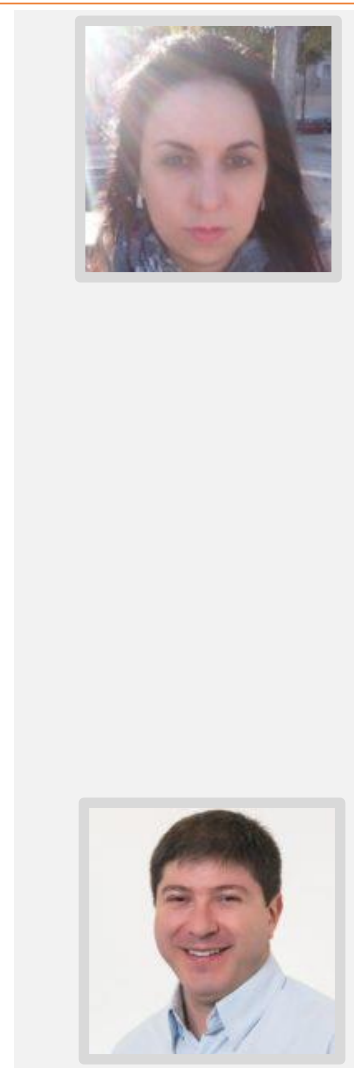

\section{Mara Raquel Ballam - Executive Manager of ABREE}

Data Processing Technician from ETEC. Technical Undergraduate Degree in Telecommunications from the FATEC. Bachelor in Law from the SBC Law School. Graduate degree in Environmental law from PUC. MBA in Sustainability from the FGV. Specialization in Corporate Social Responsibility from the FGV. Leading auditor in Quality and the Environment from the IRCA. Specialization in Six Sigma, at Green Belt and Black Belt level. 15 years' managerial experience in the fields of Quality, the Environment, Occupational Health and Safety, in addition to having developed projects in the fields of the Environment and Sustainability within the industry. Has played a significant role at governmental level through the associations of the electrical, electronic and household appliance sector, involving a series of issues, especially reverse logistics and in supporting the legislation for the control and reverse logistics of batteries and wet cells. Management of corporate social responsibility departments, especially in social projects for the FIFA World Cup in Brazil and with different organizations like UNICEF and the WWF.

\section{Fernando Gomes de Oliveira - Management and project planning - Be Digital}

Fernando Gomes de Oliveira has been working in the telecommunications and broadcasting sector since 1996, promoting technical solutions to the main TV stations, pay-TV operators and local Internet providers.At Be Digital, he is responsible for the management and planning of TV channel repacking projects with the goal of releasing the $700 \mathrm{MHz}$ band, enabling the implementation of $4 \mathrm{G}$ / LTE networks. 